\title{
Využití smíšené metodologie v profesiografickém výzkumu učitelské profese ${ }^{1}$
}

\author{
The Use of Mixed Methodology in Profesiographic Research Study of Teacher \\ Profession
}

\author{
Alena Seberová
}

\begin{abstract}
Abstrakt: Obsah př́spěvku je zaměřen na teoretické přístupy v pojetích a modelech analýzy profesí ve vztahu k aspektům a komponentám profese. Ve vazbách na pracovní motivaci, výkonnost a úspěšnost $\mathrm{v}$ profesi jsou diskutována teoretická východiska konstruktu pracovní spokojenosti, která je blíže specifikována ve dvou výchozích oblastech intrinsické a extrinsické. Možnosti využití smíšené výzkumné strategie v profesiografických studiích jsou prezentovány prostřednictvím realizovaného empirického výzkumu, jehož problémem je hledání komplementarity konstruktů pracovní spokojemnosti a úspěšnosti v učitelské profesi. Diskutován je výběr dvoufázového čistého modelu se vstupní kvantitativní a navazující kvalitativní fází šetření. Kvantitativní fázi studie reprezentují specifické cíle a dílčí výsledky testů validity a reliability dotrazníkové techniky inspirované MSQ, Minnesota Satisfaction Scale (Weiss et al., 1967). Navazující kvalitativní fáze je uvedena výzkumnými otázkami a metodami.
\end{abstract}

Klíčová slova: analýza profese; profesiografie; učitelská profese; pracovní spokojenost; úspěšnost v profesi; dvoufázový čistý model smíšené výzkumné strategie; MSQ, Minnesota Satisfaction Scale; technika kritických incidentů

\begin{abstract}
The content of the paper is focused on theoretical concepts and approaches of the work analysis / professiography in relation to the aspects and components of the profession. The links on the motivation, performance and success in the profession are discussed theoretical foundations of the construct of job satisfaction, which is further specified in two areas of intrinsic and extrinsic. Possibilities of using mixed research strategies in the professiographic studies are presented through empirical research project, which problem is finding complementarity of constructs job satisfaction and success in the teaching profession. Discussed is the selection of pure two-step model input quantitative and qualitative follow-up phases of the investigation. The quantitative phase of the study represent specific targets and partial results of tests of validity and reliability of scale technique inspired MSQ-Minnesota Satisfaction Scale (Weiss et al., 1967). Follow-up qualitative research phase is given by research questions and methods.
\end{abstract}

Keywords: job/work analysis; professiography; teacher profession; job/work satisfaction; pure two-step model of mixed research strategy MSQ, Minnesota Satisfaction Scale; critical incident technique

\footnotetext{
${ }^{1}$ Př́ispěvek je součástí výzkumného projektu APVV-0026-07 Profesia „učitel' preprimárnej edukácie“ a „učitel” primárnej edukácie“ $v$ dynamickom poňatí.
} 


\section{Teoretická východiska}

Analýzu profese (profesiografii) vymezujeme jako metodu či systém odborných procedur, jejímž úkolem je systematická a komplexní deskripce a explanace všech komponent a subkomponent profesí a oblastí práce. Profesiografické studie mají interdisciplinární charakter. Poukazováno je na komplementaritu př́stupů psychologických, pedagogických, ekonomických a sociálních (Schabracq, Winnubst, \& Cooper, 1998).

Vycházíme z komplexní verze profesiografické studie (Sanchez \& Levine, 2001; Kohoutek, 2002), která obsahuje čtyři části: detailní deskripce a analýza pracovních činností; kritéria úspěšnosti při výkonu profese a předpoklady úspěchu; nároky na pracovní výkon; aplikace výsledků do praxe.

Kritéria úspěšnosti při výkonu profese spolu s předpoklady úspěchu v podobě psychické a pracovní způsobilosti vnímáme jako zásadní „bílé místo“ českých profesiografických výzkumů učitelství. Subjektivní i objekivní předpoklady úspěchu v dané profesi vychází z vnitřních a vnějších pracovních podmínek. Ty jsou zohledňovány jak v úrovni ekonomické a organizační, tak pracovně motivační a sociálně vztahové, v rámci kterých je řešena problematika pracovní spokojenosti.

Konstrukt pracovní spokojenosti je velmi složitý a ne zcela obsahově jasný a definičně ustálený. Primárně se dotýká emoční reakce na rozličné charakteristiky práce, a to jak pozitivní tak negativní, ve smyslu reakce člověka na míru naplněného očekávání ve vazbě na práci a pracovní podmínky (Paulík, 1999; MacDonald \& MacIntyre, 1997). V tomto kontextu se opíráme o studii Weisse et al. (1967). Při standardizaci tzv. Minnesotského dotazníku (MSQ, Minnesota Satisfaction Scale) autoři prokázali pozitivní korelaci mezi pracovními potřebami jedince a pracovními podmínkami, které tvoří významové jádro pracovní spokojenosti. V dané výzkumné studii byla rovněž potvrzena existence dvou faktorů pracovní spokojenosti jako intrinsických a extrinsických oblastí pracovních podmínek (viz níže v kapitole 2).

\section{Metody}

Výzkumný problém jsme centrovali na komplementaritu konstruktů pracovní spokojemnosti a úspěšnosti v učitelské profesi. Výzkumné otázky byly formulovány následovně:

- Jak učitelé základních škol reflektují kvalitu vybraných profesních podmínek jako vnitřních a vnějších faktorů pracovní spokojenosti?

- Jaký význam má v pracovní spokojenosti fenomén úspěšnosti v profesi? Jak je učiteli úspěšnost charakterizována?

- Které atributy a uzlové body učitelé využívají k charakteristice úspěšnosti v profesi?

- Jaké postavení má učiteli subjektivně vnímaná úspěšnost $\mathrm{v}$ profesi v hodnotících reflexích pracovní spokojenosti?

Volba výzkumné strategie se odvíjela ze dvou premis. První se vztahovala na empiricky detailně zachycenou a ověřenou metodiku výzkumu konstruktu pracovní spokojenosti, která doposud nebyla $\mathrm{v}$ českých podmínkách a $\mathrm{v}$ doméně učitelské profese modifikována a testována. Druhá premisa souvisela s úmyslem porozumět komplementaritě a kauzálním vazbám mezi pracovní spokojeností a učiteli subjektivně posuzovanou úpěšností v profesi. Našim účelem bylo postihnout vícečetné aspekty těchto jevů, komplexně je popsat a vysvětlit. Tyto vybrané účely smíšené metodologie vedly k sekvenčnímu kombinování čistých strategií (Johnson \& Onwuegbuzie, 2004; Morse, 2003 in Hendl, 2005) a výběru dvoufázového čistého modelu se vstupní kvantitativní a navazující kvalitativní fází šetření. 


\subsection{Prvni fáze kvantitativní: pracovní spokojenost učiteli}

Výzkumným problémem první, kvantitativní fáze šetření bylo zjistit úroveň spokojenosti učitelů s kvalitou vybraných pracovních podmínek jako vnitřních (intrinsických) a vnějších (extrinsických) oblastí pracovní spokojenosti. Navrhnout a testovat techniku dotazníku.

Při tvorbě dotazníku jsme se inspirovali standardizovaným Minnesotským dotazníkem MSQ. Techniku jsme modifikovali pro potřeby učitelské profese. Dílčí aspekty dvou výchozích oblastí pracovní spokojenosti intrinsické a extrinsické jsou uvedeny níže. Plná verze dotazníku již byla publikována (Seberová, 2010).

Oblast intrinsická obsahovala charakteristiky: využití vlastních schopností; znalostní variabilita, celistvost, významnost, odbornost a kvalita pracovních činností; možnost osobního a profesního růstu; dosažené naplnění, úspěchu z výsledku; nezávislost: př́ležitost pracovat samostatně, nezávisle na druhých; morální hodnoty: schopnost vykonávat práci v souladu s vlastním svědomím; odpovědnost: svoboda vlastního úsudku; bezpečí psychické a sociální; sociální služba: př́ležitost pomáhat a být prospěšný druhým; rozmanitost: př́ležitost vykonávat rozličné profesní činnosti.

Oblast extrinsická obsahovala: postup, povýšení: př́ležitost pracovního/kariérního postupu; plat: platové ocenění za práci; uznání: uznání za odvedenou práci; supervize mezilidsky vztahová: způsoby, jakými ředitelé zachází se svými zaměstnanci; spolupracovníci: způsoby, jakými spolu vychází spolupracovníci; pracovní podmínky materiální a finanční; časová zátěž výkonu profese; vytrvávám ve svém pracovním úsilí; stát se učitelem bylo mé dobré životní rozhodnutí.

V pilotní fázi výzkumu jsme pracovali s dostupným souborem 61 učitelů primárního a nižšího sekundárního vzdělávání z vybraných ostravských základních škol. Pro ověření validity a reliability techniky byly využity tyto testy a výpočty:

1. Absolutních a relativních četnostní u kategorií a oblastí pracovní spokojenosti.

2. Pearsonův Chi-kvadrát test nezávislosti u proměnných 1. stupeň školy, na kterém respondenti vyučují; 2. délka praxe respondentů.

3. Faktorová analýza pro jeden a dva faktory.

4. Cronbachův koeficient alfa.

2.2 Druhá fáze kvalitativní: subjektivni pojetí úspěšnosti v profesi učitele a hledání komplementarity konstruktů pracovni spokojenosti a profesní úspěšnosti

Druhá, navazující kvalitativní etapa šetření se aktuálně nachází v projektové fázi. Výzkumné otázky byly formulovány následovně:

- Které atributy a uzlové body učitelé využívají k charakteristice úspěšnosti v profesi?

- Jak je učiteli úspěšnost charakterizována?

- Jaký význam má v pracovní spokojenosti fenomén úspěšnosti v profesi?

- Jaké postavení má učiteli subjektivně vnímaná úspěšnost $\mathrm{v}$ profesi v hodnotících reflexích pracovní spokojenosti?

- Jaké jsou relace komplementarity fenomenů pracovní spokojenosti a profesní úspěšnosti?

Z kvalitativních metod byla vybrána metoda kritických incidentů (Flanagan, 1954) a hloubkové polostrukturované interview. 


\section{Výsledky a diskuse}

Dotazníková technika sčítala 49 položek. Získali jsme tímto objemné množství dat, jež mají potenciálně vysokou výpovědní hodnotu, poněvadž detailně zachycují všechny fasety pracovní spokojenosti. Zásadní výsledky analýzy a interpretace dat již byly publikovány (Seberová, 2010). Pro účely tohoto př́spěvku jsou komentovány výsledky testi̊ validity a reliability dotazníku.

Výsledky faktorové analýzy při extrahování dvou faktorů ukázaly těsné korelace ke dvěma oblastem (tabulka 1).

\section{Tabulka 1}

Faktorová analýza pro dva faktory

Component Transformation

Matrix

\begin{tabular}{|l|r|r|}
\multicolumn{3}{|c|}{ Matrix } \\
\begin{tabular}{|l|r|} 
Compon \\
ent
\end{tabular} & \multicolumn{1}{|c|}{1} & \multicolumn{1}{c|}{2} \\
\hline 1 &, 875 &, 483 \\
2 &,- 483 &, 875 \\
\hline
\end{tabular}

Zajímavá specifika jsou u vybraných položek dotazníku ve vazbách na vnitřní a vnější oblast pracovní spokojenosti. Např. uznání za odvedenou práci a potřeba otevřených, upřímných vztahů a spolupráce s kolegy korelovaly k doméně intrinsické, přestože studie Weisse et al. (1967) potvrdila vazbu těchto aspektů na oblast extrinsickou. Povaha aspektu uznání může mít v učitelské profesi zásadní postavení dotýkající se více sociálního statusu ve smyslu př́ležitosti něco znamenat $\mathrm{v}$ odborné $\mathrm{i}$ veřejné komunitě. Podobně také potřeba otevřených, upř́mných vztahů a spolupráce $\mathrm{s}$ kolegy může poukazovat na jisté specifikum učitelské profese, nebot' se právě tato kvalita nezobrazuje pouze ve vztazích ke kolegům a vedení, ale rovněž, ne-li zásadněji, $\mathrm{k}$ žákům a jejich rodičům.

Pomocí Pearsonova korelačního koeficientu byly zjištěny vysoké hodnoty korelací obou posuzovaných oblastí, a to na signifikantní úrovni 0,01 (tabulka 2). 
Tabulka 2

Hodnoty Pearsnova korelačního koeficientu pro I. faktor intrinsické oblasti a II. Faktor extrinsické oblasti

\begin{tabular}{|c|c|c|c|}
\hline \multicolumn{4}{|c|}{ Correlations } \\
\hline & & $\begin{array}{l}\text { I. faktor } \\
\text { intrinsických } \\
\text { oblastí }\end{array}$ & $\begin{array}{l}\text { II. faktor } \\
\text { extrinsických } \\
\text { oblastí }\end{array}$ \\
\hline \multirow[t]{3}{*}{ I. faktor intrinsických oblastí } & Pearson Correlation & 1 & ,607 \\
\hline & Sig. (2-tailed) & &, 000 \\
\hline & $\mathrm{N}$ & 56 & 44 \\
\hline \multicolumn{2}{|c|}{ II. faktor extrinsických oblastí Pearson Correlation } & ,607 & 1 \\
\hline & Sig. (2-tailed) &, 000 & \\
\hline & $\mathrm{N}$ & 44 & 49 \\
\hline
\end{tabular}

Při extrahování jednoho faktoru se potvrdil jeden výchozí faktor pracovní spokojenosti (obrázek 1).

\section{Component Plot in Rotated Space}

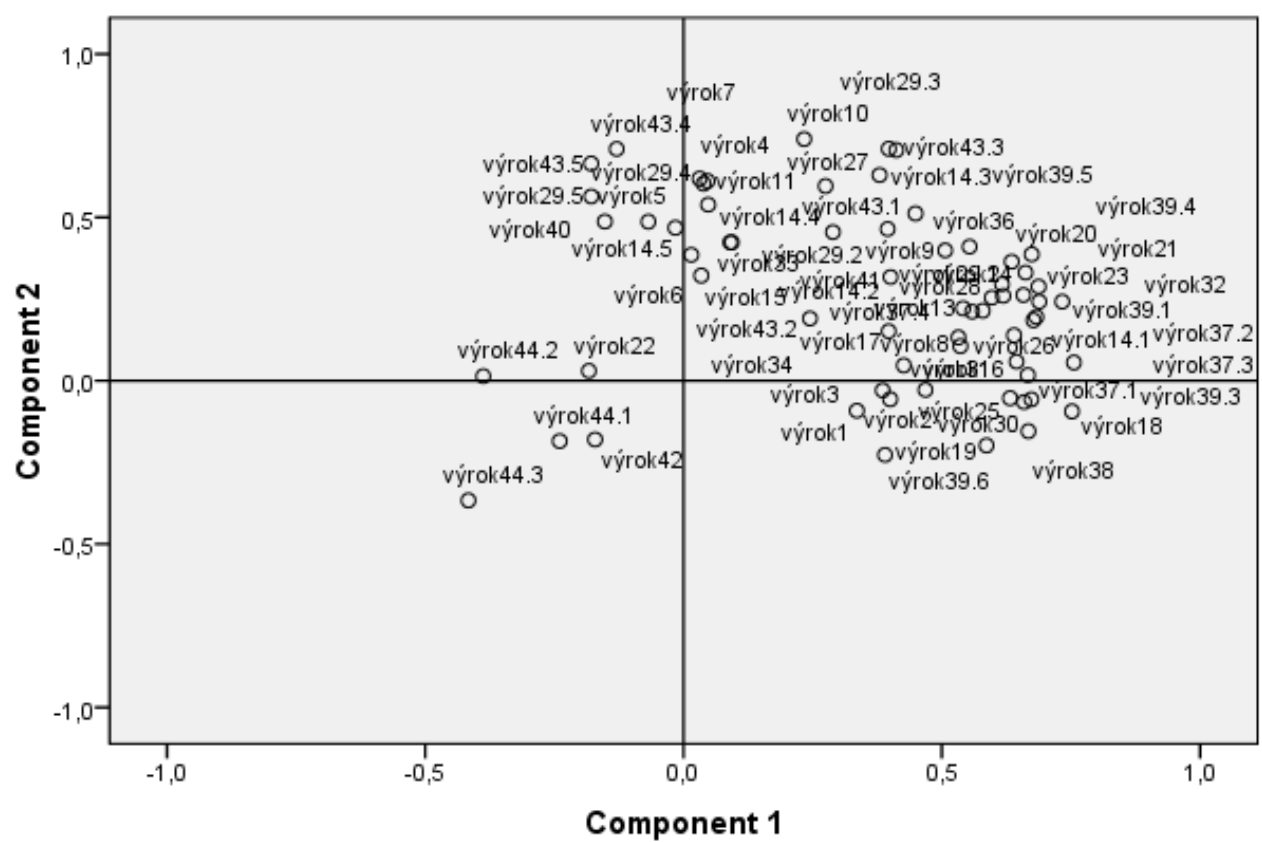

Obrázek 1. Faktorová analýza pro jeden faktor

Ve vazbě na míru korelace $\mathrm{k}$ jednomu extrahovanému faktoru se ukázaly jako problematické položky centrované na učiteli uznávané hodnoty. (Položky: Hodnoty, které uznávám, jsou v rozporu s hodnotovou orientací rodičů mých žáků, 44,1.; kolegů, 44,2.; vedení školy, 44,3.). V původní studii Weisse et al. (1967) není axiologická dimenze a její vliv na pracovní spokojenost jakkoli zastoupena. V pomáhajících profesích jako je učitelství ji však vnímáme 
jako zásadní. Proto jsme v rámci modifikace dotazníku MSQ položky s tímto obsahem zařadili. Ukázalo se, že s mírou významnosti pravděpodobně stoupá komplikovanost jejího poznání. Jednou z prŕíčin může být jistá váhavost učitelů v posuzování hodnotové orientace rodič'ů nebo kolegů, natož $\mathrm{v}$ hodnocení rozporů. Otevřená zůstává otázka vhodná pro navazující výzkumné šetření. Zda a jak preferované individuální hodnoty ovlivňují subjektivně vnímanou pracovní spokojenost člověka.

Reliabilita dotazníku byla testována pomocí Cronbachova koeficientu alfa. Jak reliabilita sumy položek s vazbou na intrinsickou a extrinsickou oblast pracovní spokojenosti, tak reliabilita jednotlivých položek vykázala velmi př́znivé hodnoty 0,892 pro faktor intrinsické oblasti (20 položek s identickou posuzovací škálou) a 0,911 pro faktor extrinsické oblasti (34 položek).

\section{Shrnutí}

Profesiografické studie potřebují detailní hloubku ve své struktuře a zaměření na jednotlivé aspekty profese, jež překračují doménu profesních činností a váží se např. na oblast subjektivně reflektované úspěšnosti $\mathrm{v}$ profesi a spokojenosti s podmínkami pro její naplňování.

Vybrané metodologické př́stupy k výzkumu pracovní spokojenosti se ukázaly jako modifikovatelné pro využití v oblasti učitelské profese. V první, kvantitativní fázi výzkumné studie byla ověřena technika dotazníku umožňující reflexi pracovní spokojenosti učitelů. Techniku bude vhodné v několika aspektech modifikovat. Svým rozsahem může být pro respondenty demotivující. Otázka konfliktu hodnot vyžaduje samostatný výzkumný přistup, strategicky kvalitativně orientovaný.

Výsledky šetření ukázaly př́mou spojitost mezi pracovní spokojeností jako systémem profesních potřeb učitelů a profesiografickou studií, na jejíž komplexnost a detailnost jsme v teoretických východiscích poukázali.

Výsledky a kritické analýzy navazující druhé, kvalitativní fáze šetření budou předmětem dalších př́spěvků.

\section{Literatura}

Flanagan, J. C. (1954). The critical incident technique. Psychological Bulletin, 51(4).

Hendl, J. (2005). Kvalitativní výzkum. Praha: Portál.

Johnson, R. B., \& Onwuegbuzie, A., J. (2004). Mixed methods research: A research paradigm whose time has come. Educational Researcher, 33(7), 14-26.

Kohoutek, R. (2002). Základy užité psychologie. Brno: Cerm 2002.

MacDonald, S., \& MacIntyre, P. (1997). The generic job satisfaction scale: Scale development and its correlates. Employee Assistance Quarterly, 13(2).

Paulík, K. (1999). Psychologické aspekty pracovni spokojenosti učiteli̊. Ostrava: OU v Ostravě.

Sanchez, J, I., \& Levine, E., L. (2001). The analysis of work in the 20th and 21st Centuries. In N. Anderson et al., Industrial, work and organizational psychology. Volume 1 - Personnel Psychology. London: SAGE.

Schabracq, M. J., Winnubst, J. A. M., \& Cooper, C. L. (1998). Handbook of work and health psychology. New York: John Wiley and Sons.

Seberová, A. (2011). Kvalita pracovního života učitelů - teoretické vize a realita empirických zjištění. In J. Wernerová (Ed.), Kam směřje současný pedagogický výzkum? Sborník př́spěvkỉ XVIII. celostátni konference ČAPV [CD-ROM]. Liberec: TU v Liberci.

Weiss, D. J., et al. (1967). Manual for the Minnesota satisfaction questionnaire. Work Adjustment Project Industrial Relations Center University of Minnesota. Dostupné z http://www.psych.umn.edu/psylabs/vpr/msqinf.htm 


\section{Kontakt}

PhDr. Alena Seberová, Ph.D.

Ostravská univerzita v Ostravě

Pedagogická fakulta

Mlýnská 5, 70103 Ostrava 1

e-mail: alena.seberova@osu.cz

\section{Bibliografické údaje}

Seberová, A. (2011). Využití smíšené metodologie v profesiografickém výzkumu učitelské profese. In T. Janík, P. Knecht, \& S. Šebestová (Eds.), Smíšený design v pedagogickém výzkumu: Sborník př́spěvků z 19. výročni konference Čské asociace pedagogického výzkumu (s. 73-79). Brno: Masarykova univerzita.

Dostupné z: http://www.ped.muni.cz/capv2011/sbornikprispevku/seberova.pdf doi: 10.5817/PdF.P210-CAPV-2012-55 